\title{
Hepatoprotective efficacy of methanolic extract of Indigofera suffruticosa (Mill) on paracetamol-induced liver damage in mice
}

\author{
Izabela Rangel LIMA' ${ }^{1}$, Ivanise Brito SILVA ${ }^{1}$, Roberta M Leite LIMA ${ }^{1}$, Tainá M Santos SILVA ${ }^{1}$, \\ Maria B Sousa MAIA² and Sônia Pereira LEITE ${ }^{1}$
}

Received 13/3/2019 Accepted 23/7/2019

\begin{abstract}
Background - Indigofera suffruticosa Mill (Fabaceae) is abundant in northeastern Brazil and popularly used in the treatment of infectious and inflammatory processes. Several biological properties, such as anti-inflammatory, anticancer, antitumor, hepatoprotective and low toxicity, are reported for this plant. Objective - This study investigated hepatoprotective activity and the antioxidant effect of methanolic extract of $I$. suffruticosa leaves (MEIS) on Swiss albino mice submitted to experimental models of acetaminophen-induced liver injury. Methods - MEIS (50 mg/kg; p.o.) was standardized according to the LD50 and its hepatoprotective property on Swiss albino mice evaluated during a 7-day period. On the eighth day, the acetaminophen-induced hepatic injury was performed. Histomorphometric analysis of liver tissue, antioxidant activity and serum levels of alanine aminotransferase (AST), aspartate aminotransferase (ALT) and bilirubin were measured. Results - MEIS (50 mg/kg; p.o.) restored serum enzyme levels and results were close to those of positive control (silymarin) when compared to the negative control. Histopathological and histomorphometric analyzes confirmed MEIS hepatoprotective activity, showing reorganization of structural units of cells, nuclei and sinusoidal capillaries of hepatocytes, reducing the damage on liver tissue and increasing organ regeneration rate. MEIS showed high antioxidant potential at concentrations of 1000 and $500 \mu \mathrm{g} / \mathrm{mL}$. Conclusion - This study suggests that MEIS has hepatoprotective activity and high antioxidant potential.
\end{abstract}

HEADINGS - Chemical and drug induced liver injury. Indigofera, drug effects. Antioxidants. Acetaminophen. Mice.

\section{INTRODUCTION}

The liver plays an important role in maintaining metabolic homeostasis and biotransformation of chemicals in the body ${ }^{(1)}$. Hepatic diseases are a worldwide health problem, and are triggered mainly by viruses, metabolic diseases or chemical compounds ${ }^{(2-4)}$.

The treatment of such diseases is carried out conventionally using synthetic pharmaceuticals, or, secondarily, by using isolated compounds or parts of medicinal plants used in popular medicine ${ }^{(5,6)}$.

However, there are still few drugs used to treat liver diseases with significant effects on humans ${ }^{(7)}$. Thus, medicinal plants with hepatoprotective or curative activity used for the treatment of hepatic disorders become important subjects of studies to elucidate their mechanism of action and characterize compounds that can be used for the development of new hepatoprotective drugs ${ }^{(8)}$.

Some experimental models are used to demonstrate the hepatoprotective action of certain plants, especially against paracetamol-induced liver damage ${ }^{(9)}$. Paracetamol may promote hepatocellular injury through three mechanisms, independently or in association. The first and most common mechanism is ingestion of doses higher than $10 \mathrm{~g}$ by adults and up to $150 \mathrm{mg} / \mathrm{kg}$ by children, popularly known as "overdose". The second mechanism is the cytochrome P450 (CYP) over activation, resulting from the use of enzyme-inducing drugs and chronic alcohol abuse. Finally, the third mechanism occurs with glucagon depletion in hepatocytes through alcohol intake or malnutrition ${ }^{(10)}$. Indigofera suffruticosa Mill (Fabaceae) is abundant in the northeastern Brazil, and has intense popular use for treatment of infections, inflammations and other processes, without reports of harmful side effects to humans. The phytochemical investigation of leaf extracts of I. suffruticosa revealed the presence of alkaloids, flavonoids, steroids, proteins, carbohydrate, triterpenes and indigo coumarin ${ }^{(11,12)}$ and, the chemical properties of two compounds isolated from I. suffruticosa leaves (indigo and indirubin) were identified, isolated and purified by Vieira et al. ${ }^{(13)}$. Later, the bis-indolic alkaloid fraction of leaves of I. suffruticosa was investigated and proved to be a phytotherapeutic agent of liver ${ }^{(14)}$. Pharmacological studies showed aqueous extracts of leaves of I. suffuticosa have anti-inflammatory, antimicrobial and embryotoxic properties, besides being used as alternative anticancer and antitumor therapy ${ }^{(12,15-18)}$. The aqueous leaf extract of I. suffruticosa has been shown to inhibit egg hatching, larval ecdyse and to have detergent effects on oviposition of Aedes aegypti mosquitoes ${ }^{(19)}$. Mice carrying sarcoma 180 had positive hepatic response to subchronic treatment with methanolic extract of I. suffruticosa leaves ${ }^{(20)}$. The structural organization of the renal tubules and hepatocyte nuclei of mice were preserved after treatment with I. suffruticosa $a^{(21,22)}$. The aqueous extract of I. suffruticosa leaves has low toxicity, with $98 \%$ viability of larvae ${ }^{(19)}$.

Declared conflict of interest of all authors: none

Disclosure of funding: This study was supported by the Coordinator of Improvement of Higher Level Personnel (CAPES) and National Council of Scientific and Technological Development (CNPQ) at Federal University of Pernambuco (UFPE)

${ }^{1}$ Universidade Federal de Pernambuco, Laboratório de Histomoformetria, Departamento de Histologia e Embriologia Recife, PE, Brasil. ${ }^{2}$ Universidade Federal de Pernambuco, Laboratório de Produtos Naturais e Bioativos, Departamento de Fisiologia e Farmacologia, Brasil.

Corresponding author: Sônia Pereira Leite. E-mail: spleite6@hotmail.com 
Due to the anti-inflammatory, anticancer and antitumor properties, and because it is a liver protective agent with previously reported low toxicity, we hypothesize the plant can be used as a hepatoprotective phytotherapic agent. This study investigated the effect of I. suffruticosa on the hepatoprotective activity as well as its antioxidant effect through an experimental model of paracetamolinduced hepatic lesion in Swiss albino mice.

\section{METHODS}

\section{Chemicals}

Methanol, distilled water, $10 \%$ formalin, sodium chloride $(0.9 \%$ $\mathrm{NaCl}$ ), hematoxylin, eosin, silymarin and acetaminophen were supplied by Merck (Germany).

\section{Plant material and extraction}

Leaves of I. suffruticosa were collected in the city of Recife, state of Pernambuco, Brazil, in July 2014. The sample was certified by the biologist Marlene Barbosa from the Department of Botany at the Federal University of Pernambuco (UFPE) and it is deposited under the n. 43694 in the Herbarium of the Center for Biological Sciences - (UFPE). Leaves of I. suffruticosa $(1.3 \mathrm{~kg})$ were washed in running water, pulverized and extracted with methanol $(\mathrm{MeOH})$ at room temperature for 48 hours. Then, the solvent was filtered and evaporated at $35^{\circ} \mathrm{C}$ under reduced pressure. The methanolic extract of I. suffruticosa leaves (MEIS) yielded $54.5 \mathrm{~g}$. Fresh dilution of dried extract in saline solution $(0.9 \% \mathrm{NaCl})$ was prepared on the day of experiments.

\section{Experimental animals}

Eighteen healthy male Swiss albino mice, aged 40 days, weighing on average 35 to $45 \mathrm{~g}$ were acquired from the Aggeu Magalhães Research Center (Pernambuco, Brazil). Animals had free access to water and feed. They were kept under standard environmental conditions of temperature, humidity 12:12 light-dark cycle. The Committee on Animal Research and Ethics of UFPE approved the experiments under opinion n. 500/12, process $n$. 23076.025195/2012-64 of 2012.

\section{Experimental design and treatment arrangement}

Swiss albino mice were randomly divided into three groups $(\mathrm{n}=6$ animals/group) and orally pre-treated during seven days before paracetamol-induced liver damage, according their respective group: G1 - treated with saline $(15 \mathrm{~mL} / \mathrm{kg}$; p.o.), $\mathrm{G} 2$ - treated with Silymarin $(25 \mathrm{mg} / \mathrm{kg}$; v.o.) and G3 - treated with MEIS $(50 \mathrm{mg} / \mathrm{kg}$; v.o.). The I. suffuticosa extract dose was based on LD50 ${ }^{(19)}$. In the eighth day, after fasting for $12 \mathrm{~h}$, the mice were administered with paracetamol (300 mg $/ \mathrm{kg}$; v.o.). Twenty four hours later, blood was gained through cardiac puncture, and serum was separated for later determination of alanine aminotransferase (ALT), aspartate aminotransferase (AST) and bilirubin. Following they were euthanized cervical dislocation for collection of liver samples.

\section{Levels of transaminases}

Serum enzyme levels (alanine aminotransferase (ALT), aspartate aminotransferase (AST) and bilirubin of groups G1, G2 and G3 of Swiss albino mice submitted to pretreatment with IS extract prior to paracetamol-induced hepatic injury were analyzed using commercial kits according to the manufacturer's protocols.
Histopathological and histomorphometric analysis of liver

The liver of control groups (G1 and G2) and treatment group (G3) were fixed in $2.5 \%$ formaldehyde and stained with hematoxylin and eosin $(\mathrm{HE})^{(23)}$. Thirty histological sections were analyzed through four random fields. The histological sections were digitized using a digital video camera (Leica DFC 280, Wentzler, Germany) coupled to a light microscope (Leica Microscopy \& Systems GmbH, Wentzler, Germany) under 40x final magnification. Morphometric evaluation, the perimeter of hepatocyte nuclei and the diameter of sinusoidal capillaries were determined using the Scion Image software (Scion Corporation, New York, USA).

\section{In vitro antioxidant assay - DPPH radical scavenging activity}

The antioxidant activity of MEIS was determined by using a 1,1-diphenyl-2-picrylhydrazyl (DPPH) assay. Briefly, different concentrations of MEIS $(1,000,500,250$ and $125 \mu \mathrm{g} / \mathrm{mL})$ and DPPH $(0.4 \mathrm{mM})$ were prepared in ethanol. For determination of MEIS antioxidant activity, sample were mixed with DPPH solution (1:1; $\mathrm{v} / \mathrm{v})$ for 40 minutes at room temperature. After incubation period, the absorbance of the solution was measured at $517 \mathrm{~nm}$ using a microplate reader and related to the negative control (DPPH and ethanol). All tests were carried out in triplicate, and the ability to eliminate DPPH (\% of antioxidant activity) was calculated using the following equation:

$$
\text { Elimination }[\mathrm{DPPH}] \%=\frac{(\text { Abs sample }- \text { Abs control })}{\text { Abs control }} \times 100
$$

\section{Statistical analysis}

The results for levels of transaminases, as well as histopathological and histomorphometric parameters of hepatocytes nuclei $=$ were expressed as mean \pm SEM (standard error of the mean) and analyzed by Kruskal-Wallis test at $P<0.001$. The antioxidant activity was analyzed by Tukey test $(P \leq 0.05)$ using the Assistat software - version 7.6 beta.

\section{RESULTS}

\section{Levels of transaminases}

TABLE 1 shows the serum levels of alanine aminotransferase (ALT), aspartate aminotransferase (AST) and bilirubin of Swiss albino mice treated with MEIS prior to paracetamol-induced hepatic injury (PCM). The animals of the group (G1) showed high levels of

TABLE 1. Serum levels of alanine aminotransferase (ALT), aspartate aminotransferase (AST) and bilirubin in Swiss albino mice treated with MEIS prior to paracetamol-induced hepatic injury (PCM).

\begin{tabular}{lcccc}
\hline Group & $\begin{array}{c}\text { Dose } \\
(\mathrm{mg} / \mathrm{kg})\end{array}$ & ALT (IU/L) & AST (IU/L) & $\begin{array}{c}\text { Bilirubin } \\
(\mathrm{mg} / \mathrm{L})\end{array}$ \\
\hline $\mathrm{G} 1$ & $15 \mathrm{~mL} / \mathrm{kg}$ & $94.48 \pm 6.89 * *$ & $120.98 \pm 13.67 * *$ & $7.9 \pm 3.5 * *$ \\
$\mathrm{G} 2$ & $25 \mathrm{mg} / \mathrm{kg}$ & $31.36 \pm 4.78$ & $36.65 \pm 5.35$ & $1.4 \pm 0.5$ \\
$\mathrm{G} 3$ & $50 \mathrm{mg} / \mathrm{kg}$ & $37.78 \pm 4.56 *$ & $39.24 \pm 5.78^{*}$ & $2.1 \pm 1.2 *$ \\
\hline
\end{tabular}

Results are expressed as mean \pm SEM. * Statistically significant compared to animals treated with saline solution $(P<0.05)$.** Statistically significant for animals treated with silymarin and Indigofera suffruticosa extract $(P<0.05)$. 
ALT (94.48 \pm 6.89$)$, AST (120.98 \pm 13$)$ and bilirubin (7.9 \pm 3.5$)$ compared to animals treated with silymarin (G2): ALT (31.36 \pm 4.78$)$, AST (36.65 \pm 5.35$)$ and bilirubin (1.4 \pm 0.5$)$, which reduced serum enzyme levels. Results of G2 were close to those treated with MEIS

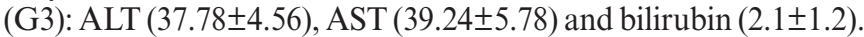
The reduction in serum levels of these important markers related to liver integrity suggests a hepatoprotective activity of MEIS against paracetamol-induced hepatic injury.

\section{Histopathological and histomorphometric analysis of liver}

Hepatic tissue samples collected from each group on the eighth day were evaluated at 400x magnification. A photomicrograph of each group is shown in FIGURE 1. Histological analysis of hepatic tissue after pretreatment with MEIS (50 mg/kg; p.o.) (G3) and the positive control $(\mathrm{G} 2)$ receiving silymarin $(25 \mathrm{mg} / \mathrm{kg})$ prior to paracetamol-induced hepatic injury showed normal hepatic tissue. Lobular central vein $(\mathrm{CV})$ radiating out of the vein, wellreorganized hepatocyte cords $(\mathrm{HC})$ in the structural units of cells among which are the well-arranged sinusoidal capillaries (S), suggesting a possible angiogenic action compared to the negative saline control (G1). The G1 showed structural differences in the hepatic tissue whose hepatocyte cords (HC) showed no organized cellular structural units, congested sinusoidal capillaries (S) and areas of necrosis with discrete leukocyte infiltration (LI).

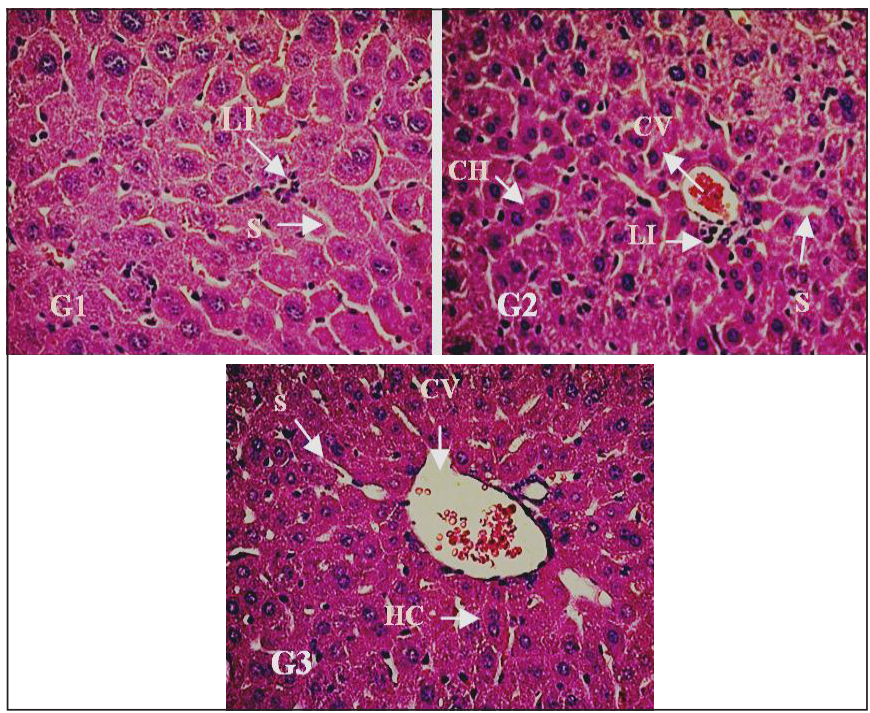

FIGURE 1. Photomicrograph of hepatic tissue of Swiss albino mice (Magnification 400x). G1: hepatic tissue/administered saline solution; G2: hepatic tissue/administered Silymarin; G3: hepatic tissue/administered MEIS Formalin-fixed, HE - stained. Leukocyte Infiltration (LI), sinusoid capillaries (S), central veins $(\mathrm{CV})$, hepatocytes cords $(\mathrm{CH})$.

\section{Area and perimeter of hepatocyte nuclei}

The areas and perimeters of hepatocyte nuclei of the three groups were randomly compared and are shown in FIGURES 2 and 3 . The areas and perimeters of G3 $(0.106 \pm 0.025$ and $1.145 \pm 0.140)$ showed no significant difference compared to those of G2 $(0.094 \pm 0.027$ and $1.082 \pm 0.150)$. However, the areas and perimeters of G1 $(0.434 \pm 0.127$ and $1.650 \pm 0.669)$ showed significant difference when compared to those of G2 $(0.094 \pm 0.027$ and $1.082 \pm 0.150)$ and $\mathrm{G} 3(0.106 \pm 0.025$ and $1.145 \pm 0.140)(P<0.001)$.

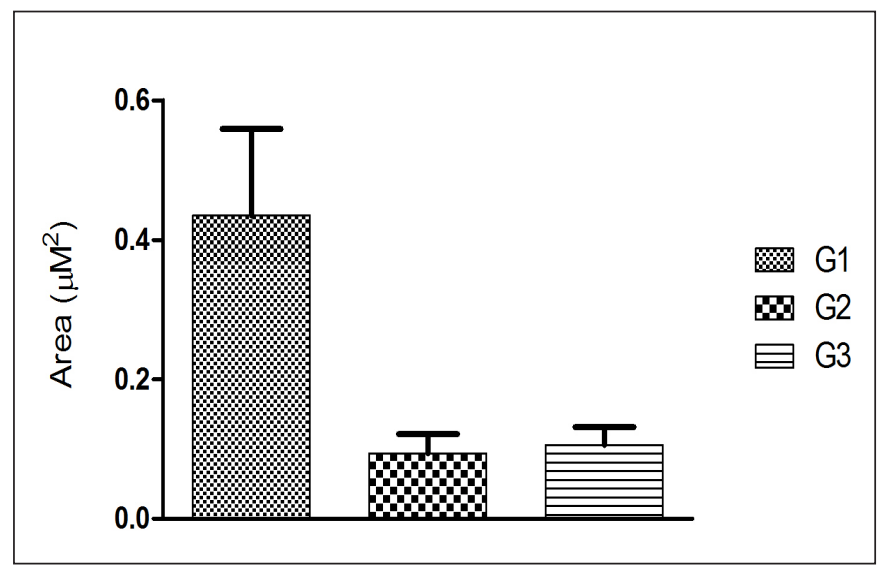

FIGURE 2. Histomorphometry of the area of hepatocyte nuclei of mice: G1: hepatic tissue/administered saline solution; G2: hepatic tissue/administered Silymarin; G3: hepatic tissue/administered MEIS. The data were analyzed by analysis of variance using the Tukey test $(P<0.001)$. N- 240 hepatocyte nuclei.

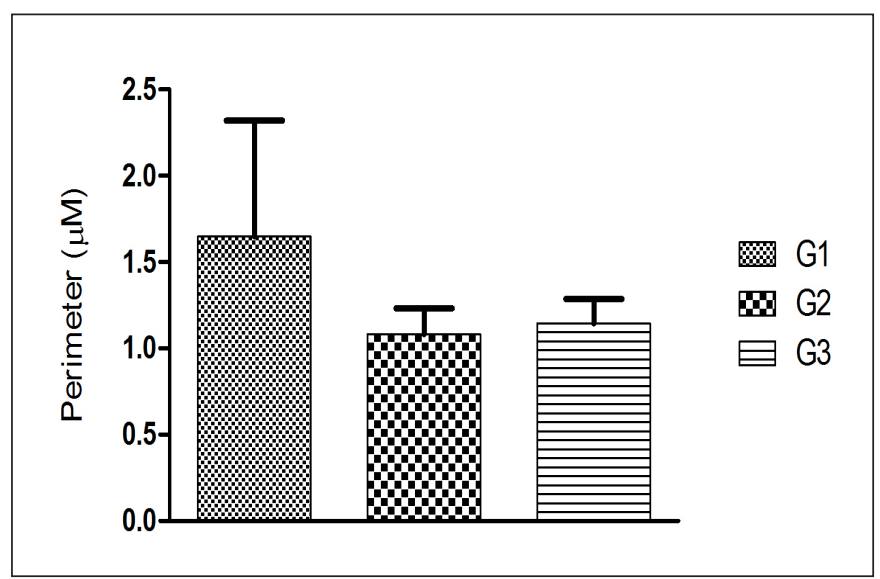

FIGURE 3. Histomorphometry of the perimeter of hepatocyte nuclei of mice: G1: hepatic tissue/administered saline solution; G2: hepatic tissue/ administered Silymarin; G3: hepatic tissue/administered MEIS. The data were analyzed by analysis of variance using the Tukey test $(P<0.001)$. N- 240 hepatocyte nuclei.

\section{Diameter of hepatic sinusoidal capillaries}

Sinusoidal capillaries of G3, subjected to subchronic pretreatment MEIS (50 mg/kg; p.o.), G2 positive control/silymarin and G1negative/saline solution, were randomly compared and are shown in FIGURE 4. The hepatic sinusoidal capillaries of G3 mice

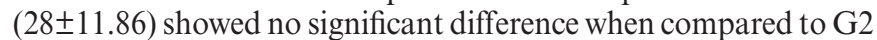

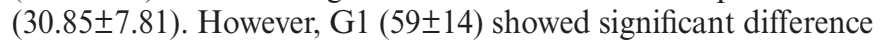
when compared to $\mathrm{G} 2(30.85 \pm 7.81)$ and $\mathrm{G} 3(28 \pm 11.86)(P<0.001)$.

\section{In vitro antioxidant activity of MEIS by DPPH free-radical scanning method}

The MEIS antioxidant potential is shown in FIGURE 5: $73.79 \% \pm 1.5915$ of antioxidant activity at $1,000 \mu \mathrm{g} / \mathrm{mL} ; 79.58 \%$ \pm 1.0231 at $500 \mu \mathrm{g} / \mathrm{mL} ; 67.25 \% \pm 2.6531$ at $250 \mu \mathrm{g} / \mathrm{mL}$ and $57.12 \%$ \pm 0.4641 at $125 \mu \mathrm{g} / \mathrm{mL}$. Results suggest MEIS have great antioxidant potential at 1,000 and $500 \mu \mathrm{g} / \mathrm{mL}$ and may contain substances capable of donating electrons; thus reducing free radicals. 


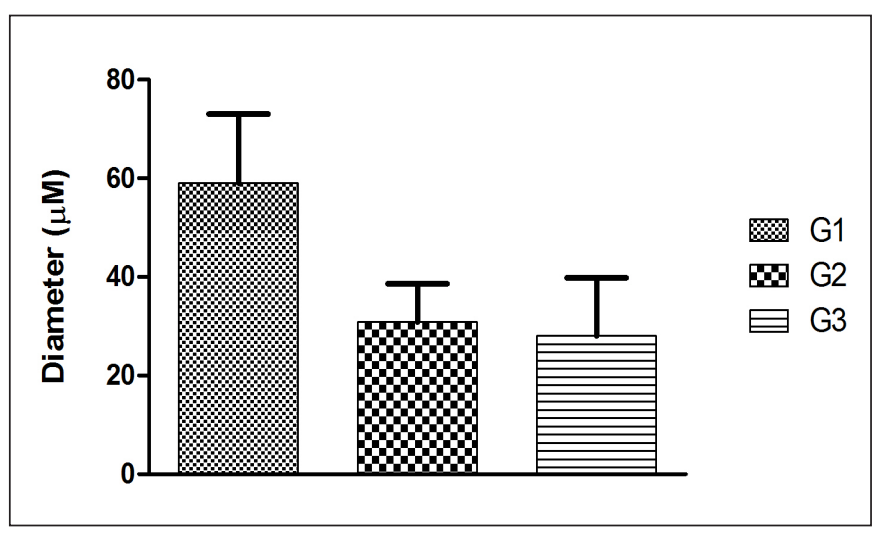

FIGURE 4. Histomorphometry of the diameter of hepatic sinusoids capillaries of mice: G1: hepatic tissue/administered saline solution; G2: hepatic tissue/administered silymarin; G3: hepatic tissue/administered MEIS. The data were analyzed by analysis of variance using the Tukey test $(P<0.001)$. N- 240 hepatic capillaries.

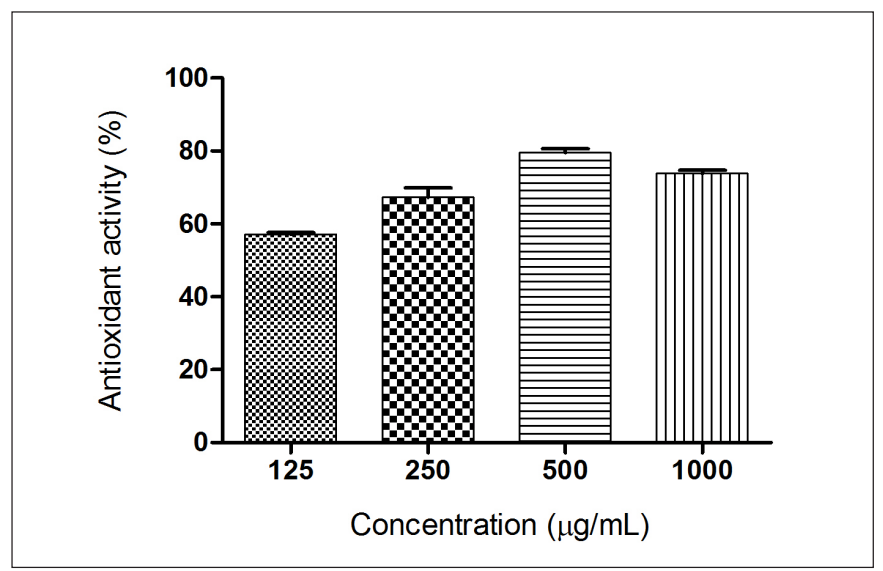

FIGURE 5. Comparison of the antioxidant activity of the MEIS at different concentrations. The data were analyzed by analysis of variance using the Tukey test $(P<0.001)$.

\section{DISCUSSION}

Liver diseases are a worldwide health problem mainly triggered by viruses, metabolic diseases or chemical compounds ${ }^{(2-4)}$. The hepatoprotective activity of plant extracts and compounds has been verified through the model of paracetamol-induced intoxication $(\mathrm{PCM})^{(9,24-27)}$. The increase in serum enzyme levels is among the evidence of PCM-induced hepatic injury ${ }^{(28)}$. Serum enzymes levels act as markers reflecting both hepatocellular necrosis and their release into the blood after damage to cell membrane ${ }^{(29,30)}$.

I. suffruticosa has been used in traditional medicine for the treatment of infections and inflammation without reports of side effects to humans. These data were demonstrated by its properties: anti-inflammatory, embryotoxic, antimicrobial, anticancer, antitumor, hepatoprotective and low toxicity ${ }^{(12,15-18,20)}$. This study investigated the effects of MEIS on paracetamol-induced liver injury and its in vitro antioxidative action on Swiss albino mice.

Mice pretreated with MEIS prior to paracetamol - induced hepatic injury showed restoration of serum enzyme levels of ALT, AST and bilirubin, reduced hepatic tissue damage and increased organ regeneration rate. MEIS (50 mg/kg; p.o.) restored serum enzyme levels and results were close to those of positive control (silymarin) when compared to the negative control. This effect was similar to the group treated with silymarin. Possibly, this effect is associated with the extract antioxidant activity. On the other hand, the negative control presented increasing ALT, AST and bilirrubine serum levels. The serum enzyme levels using Caralluma umbellate, a perennial and succulent herb, were investigated. Pretreatment with ethanolic extract followed by paracetamol administration led to reduced levels of total bilirubin, cholesterol, ALT, AST, and alkaline phosphatase. The extract showed hepatoprotective activity for restoring serum enzyme levels and preventing oxitive stress ${ }^{(31)}$. Similar data were described for Melia azedarach L. (cinnamon) used for treatment of leprosy and inflammatory processes. The methanolic extract of Melia azedarach $(500 \mathrm{mg} / \mathrm{kg}$ ) administered in rats for seven days, followed by the paracetamol administration on the 5th day showed a hepatoprotective activity, reducing levels of AST, ALT and alkaline phosphatase and increasing enzyme activity (27). The hepatoprotective potential in our study was due to the MEIS pretreatment at $50 \mathrm{mg} / \mathrm{kg}$, which showed restoration of normal physiology of serum enzyme levels. These data can be corroborated by histological analysis of liver. Histological analysis is an important tool for detection of morphological changes in the liver caused by bioactive compounds. The results of histological analysis showed structural organization in the hepatic tissue of mice subjected to paracetamol-induced injury after subchronic pretreatment with MEIS, similarly to the positive control/silymarin. However, hepatic tissue changes observed for the negative/saline solution control included: congested sinusoids, changes in hepatocyte cords and areas of necrosis and hemorrhage, characterizing leukocyte infiltration. Our data corroborate the results found by Silva et al. ${ }^{(21)}$ who demonstrated that the aqueous extract of I. suffriticosa leaves preserved the liver architecture, suggesting its use as alternative hepatoprotective agent ${ }^{(21)}$. In this study, there was reorganization of hepatocyte structural units and s inusoidal capillary cells, suggesting a possible angiogenic action in the liver of mice treated with MEIS and corroborating the pharmacological, anti-inflammatory, anticancer and antitumor properties of the extract ${ }^{(15,17,18)}$.

The histomorphometric analysis of the area and perimeter of hepatocyte nuclei and diameter of sinusoidal capillaries of mice subjected to paracetamol-induced injury after subchronic treatment with MEIS were similar when compared to silymarin. The groups pretreated with MEIS or silymarin showed no significant statistical differences. These data corroborate histological and morphometric analyses of experiments performed by Lima et al. (2014) who showed the absence of a structural change in the hepatic epithelium of mice carrying sarcoma 180 after treatment with Indican isolated of methanol extract from I. suffruticosa leaves. However, significant changes were observed in the control group with sarcoma $180^{(14)}$.

The nuclei and sinusoidal capillaries of hepatocytes after subchronic treatment with extract and silymarin showed protective effect on the hepatic tissue of mice compared to the negative control. The results of this study suggest a possible angiogenic action due to a structural reorganization of glandular epithelial tissue, cells, nuclei and sinusoidal capillaries of hepatocytes after subchronic treatment with MEIS. This may also be due to its interference with DNA synthesis. The same mechanisms of aqueous extract of I. suffruticosa may be involved in the embryo development in mice ${ }^{(16)}$. Biological activities of compounds detected in 
the methanolic extract of I. suffruticosa leaves may be related to the antitumor activity found by Vieira et al. ${ }^{(18)}$. Other studies have reported the preservation of structural organization of renal tubules and hepatocyte nuclei of mice following treatment with I. suffruticosa $a^{(20,22)}$.

Muthulingam et al., using paracetamol as acute hepatotoxicity model, reported that the treatment of animals with aqueous extract of Indigofera tinctoria showed marked reduction of necrosis and liver tissue degeneration ${ }^{(30)}$. The efficacy of any hepatoprotective drug is essentially dependent on its ability to reduce harmful effects or maintain the normal hepatic physiology that has been disrupted by a hepatotoxin ${ }^{(31,32)}$. Silymarin extracted from seeds of Marian thistle (Silybum marianum) consists of many polyphenolic flavonoids, including silibinin (the main one), isosilybine, silycristin and silydianin ${ }^{(33)}$. Silymarin has been used for centuries because of its known hepatoprotective effects and several pharmacological properties ${ }^{(32)}$.

Lipid peroxidation is a chain reaction of polyunsaturated fatty acids of cell membranes generating free radicals that change their permeability, fluidity and integrity ${ }^{(33)}$. Antioxidant activity provides health benefits by inhibiting lipid peroxidation ${ }^{(34)}$. The percentage of antioxidant activity is proportional to the amount of DPPH consumed by the sample ${ }^{(35,36)}$. Thus, the higher the DPPH consumption per sample, the lower its absorbance and the higher its antioxidant activity.

Our study on the antioxidant activity of MEIS $(1,000 \mu \mathrm{g} / \mathrm{mL}$ and $500 \mu \mathrm{g} / \mathrm{mL}$ ) suggests the presence of substances capable of donating electrons and thus reducing free radicals. These results suggest that MEIS have a great antioxidant potential directly related to the concentration increase. These results are similar to those found by Renukadevi et al. for methanolic extracts of Indigofera tinctoria, which showed significant antioxidant activity at the concentrations tested $^{(37)}$. The hepatoprotective activity of MEIS found in this study is probably related to chemical compounds capable of donating electrons and reducing free radicals ${ }^{(38)}$; a fact confirmed by the antioxidant activity of this plant that induces the inhibition of the tissue injury according to studies reported in the pertinent literature ${ }^{(39)}$. Also, other studies are recommended to evaluate the curative efficacy on hepatic tissue of mice in experimental models of paracetamol-induced hepatic injury subjected to post-treatment with MEIS. In conclusion, this study suggests that hepatic tissue of mice in experimental models of paracetamol-induced hepatic injury subjected to pretreatment with MEIS showed restoration of hepatic physiology at serum enzyme levels, reorganization of tissue structural units, hepatic sinusoidal cells and capillaries, besides antioxidant potential, indicating reduced damage to the hepatic tissue and increased organ regeneration rate. These data suggest that MEIS has hepatoprotective activity.

\section{Authors' contribution}

Professor Leite SP: author responsible for the integrity of the work. All authors Lima IR, Silva IB, Lima RML, Silva TMS were involved in the development of the research, collection of plant material preparation of the extract as well as histopathology and histomorphometry of hepatic tissue and the antioxidant potential. Professor Maia MBS: contributed to the experimental design and treatment schedule and to the analysis of enzymatic dosages.

\section{Orcid}

Izabela Rangel Lima. Orcid: 0000-0002-3137-8415.

Ivanise Brito da Silva. Orcid: 0000-0003-3605-0344.

Tainá Maria dos Santos Silva. Orcid: 0000-0002-8142-1995.

Roberta Maria Pereira Leite de Lima. Orcid: 0000-0002-87456398.

Maria Bernadete de Sousa Maia. Orcid: 0000-0003-4616-2681. Sonia Pereira Leite. Orcid: 0000-0002-0634-9735.

Lima IR, Silva IB, Lima RML, Silva TMS, Maia MBS, Leite SP. Eficácia hepatoprotetora do extrato metanólico de Indigofera suffruticosa (Mill) em lesão hepática induzido por paracetamol em camundongos. Arq Gastroenterol. 2019;56(4):333-8.

RESUMO - Contexto - Indigofera suffruticosa Mill (Fabaceae) é abundante no nordeste do Brasil e popularmente utilizada no tratamento de processos infecciosos e inflamatórios. Várias propriedades biológicas, como anti-inflamatório, anticâncer, antitumoral, hepatoprotetor e baixa toxicidade, são relatadas para esta planta. Objetivo - Este estudo investigou a atividade hepatoprotetora e o efeito antioxidante do extrato metanólico de folhas de I. suffruticosa (MEIS) em camundongos albinos suíços submetidos a modelos experimentais de lesão hepática induzida por paracetamol. Métodos O MEIS na dose de $50 \mathrm{mg} / \mathrm{kg}$ (via oral) foi padronizado de acordo com a LD50 e sua propriedade hepatoprotetora em camundongos albinos Swiss avaliados durante um período de sete dias. No oitavo dia, a lesão hepática foi induzida por paracetamol em todos grupos pre-tratados. Foram medidos os níveis sericos enzimaticos, alanina aminotransferase, aspartato aminotransferase e bilirrubina, análise histomorfométrica do tecido hepático e atividade antioxidante. Resultados - O MEIS restaurou os níveis séricos de enzimas e os resultados foram próximos aos do controle positivo (silimarina) quando comparados ao controle negativo. As análises histopatológicas e histomorfométricas confirmaram a atividade hepatoprotetora do MEIS, mostrando reorganização das unidades estruturais das células, núcleos e capilares sinusoidais dos hepatócitos, reduzindo os danos no tecido hepático e aumentando a taxa de regeneração de órgãos. O MEIS apresentou alto potencial antioxidante nas concentrações de 1000 e $500 \mu \mathrm{g} / \mathrm{mL}$. Conclusão Este estudo sugere que I. suffruticosa tem atividade hepatoprotetora e alto potencial antioxidante.

DESCRITORES - Doença hepática induzida por substâncias e drogas. Indigofera, efeitos dos fármacos. Antioxidantes. Acetaminofen. Camundongos. 


\section{REFERENCES}

1. Brasileiro Filho, G. Patologia. 6 eds. Rio de Janeiro: Guanabara Koogan. 2000

2. Negi AS, Kumar JK, Luqman S, Shanker K, Gupta MM, Khanuja SP Recent advances in plant hepatoprotectives: A cheminal and biological prolife of some important leads. Medicinal Research Reviews. 2008;28:746-72.

3. Graier W, Malli R, Kostner GM. Mitochondrial protein phostorrylation instigator or target of lipotoxicity? Trends Endocrinol Metab. 2009;20:186-93.

4. Lens S, Crespo G, Carrión JA, Miquel R, Navasa MCrespo G, Carrión JA, Miquel R, Navasa M. Severe acute hepatitis in the dress syndrome: Report of two cases Annals of Hepatology. 2010;9:198-201.

5. Aktay G, Deliorman D, Ergun E, Ergun F, Yesilada E, Cevik C. Hepatoprotective effects of Turkish folk remedies on experimental liver injury. J Ethnopharmacol. 2000;73:121-9.

6. Dhiman, Chawla D. Herbal Medicines for Liver Diseases Digestive. Dig Dis Sci. 2005;50:1807.

7. Muriel P, Rivera-Espinoza Y. Beneficial drugs for liver diseases. J Appl Toxicol. 2008;28:93-103.

8. Girish C, Koner BC, Jayanthi S, Ramachandra Rao K, Rajesh B, Pradhan SC Hepatoprotective activity of picroliv, curcumin and ellagic acid compared to silymarin on paracetamol induced liver toxicity in mice. Fundam Clin Pharmacol. 2009;23:735-45

9. Kumar G, Banu GS, Pappa PV, Sundararajan M, Pandian MR. Hepatoprotective activity of Trianthema portulacastrum L.against paracetamol and thioacetamide intoxication in albino rats. J Ethnopharmacol. 2004;92:37-40.

10. Lopes J, Matheus ME. Risk of hepatotoxicity with Acetaminophen. Rev. Bras. Farm. 1012;93:411-4.

11. Leite SP. Indigofera Suffruticosa Mill: ensaio fitoquímico e ações biológicas Tese (Doutorado em produtos naturais). João Pessoa: Universidade Federal da Paraíba. 2003. 01-90.

12. Leite SP, Vieira JRC, Medeiros PL, Leite RMP, Li.ma VLM, Xavier SH, Lima EO. Antimicrobial activity of Indigofera suffruticosa. Evid Based Complement Alternat Med. 2006;3:261-5.

13. Vieira JRC. Investigação farmacognóstica e biológica de folhas de Indigofera suffruticosa Mill sobre Aedes aegypti. Tese (Doutorado em Ciências Farmacêuticas) - Departamento de Ciências Farmacêuticas. Recife: Universidade Federal de Pernambuco, 2011

14. Lima IR, Vieira JR, Silva IB, Leite RM, Maia MB, Leite SP. Indican from Anil (Indigofera suffruticosa Miller): An herbal protective agent in liver. Analytical and Quantitative Cytology and Histology. 2014;36:41-5.

15. Leite SP, Silva LLS, Catanho MTJA, Lima EO, Lima VLM. Anti-inflammatory Activity of Indigofera suffruticosa extract. REBRASA. 2003;7:47-52.

16. Leite SP, Medeiros PL, Silva, EC, Maia MBS, Lima VLM, Saul DE, Embryotoxicity in vitro with extract of Indigofera suffruticosa leaves. Birth Defects Res B Dev Reprod Toxicol. 2004;701-5.

17. Vieira JRC, Souza IA, Nascimento SC, Leite SP. Indigofera suffruticosa: an alternative anticancer therapy. Evidence-Based Complementary and Alternative Medicine. 2007;1-5.

18. Vieira JRC, Souza IA, Nascimento SC, Leite SP. Antitumoral ctivity of indigofera suffruticosa. - An. Fac. Med. Univ. Fed. Pernambuco. 2007; 52:12-4.

19. Vieira JRC, Leite RMP, Lima IR. Navarro DAF, Bianco EM, Nascimento SC, Leite SP. Oviposition and Embryotoxicity of Indigofera suffruticosa on Early Developmentof Aedes aegypti (Diptera: Culicidae). Evid Based Complement Alternat Med. 2012;741638:1-6.

20. Lima IR. Investigação da Indigofera suffruticosa sobre atividade antitumoral e aspectos histológicos e morfométricos do tecido hepático de camundongos portadores de sarcoma 180. Dissertação (Mestrado - Programa de Pós-graduação em Inovação Terapêutica. Universidade Federal de Pernambuco), Recife. 2012.

21. Silva IB, Lima IR, Santana MAN, Leite RMP, Leite SP. Indigofera suffruticosa Mill (fabaceae): hepatic responses on mice bearing Sarcoma 180. Int. J. Morphol. 2014:32:1228-33.

22. Santana MAN, Silva IB, Lima IR, Vieira JRC, Leite RMP, Leite SP. Histomorphometric analysis in kidney tissue of mice treated with Indigofera suffruticosa Mill. J Pharm Pharm Sci. 2015;7:12-8.

23. Masson P. Tumors Humanism: Histologic. Diagnostics et Techniques. 2a ed Paris, Libraire Maloine. 1956;106-48.

24. Singh SS, Handa. Hepatoprotective activity of Apium graveolens and Hygrophila auriculata against paracetamol and thioacetamide intoxication in rats. J Ethnopharmacol. 195;49:119-26.

25. Ahmed MF, Rao AS, Thayyll H, Ahemad SR. Role of Melia azedarach leaf extract in Paracetamol Induced Hepatic damage in rats. Pharmacognosy Journal 2011;3:60-4

26. Kaplowitz N. Drug-induced liver disorders: implications for drug development and regulation. Drug Safety. 2001;24:483-90.

27. Choi JS, Yoon TJ, Kang KR, Lee KH, Kim WH, Suh YH, Song J, Jung MH Glycoprotein Isolated from Acanthopanax senticosus Protects against Hepatotoxicity Induced by Acute and Chronic Alcohol Treatment. Biol Pharm Bull. 2006;29:306-14

28. Janbaz KH, Gilani AH. Studies on preventive and curative effects of berberine on chemical-induced hepatotoxicity in rodents. Fitoterapia. 2000;71:25-33.

29. Shanmugam G, Ayyavu M, Rao DM, Devarajan T, Subramanim G. Hepatoprotective effect of Caralluma umbellate against acetaminophen induced oxidative stress and liver damage in rat. J Pharm Res. 2013;6:342-5.

30. Renteria IB, Corona MRC, Rosales PC, Garza HGL, Nava DC, Mendosa FJA, Cantú EMT. Hepatoprotective effect of Leucophyllum frutescens on Wistar albino rats intoxicated with carbon tetrachloride. Ann Hepatol. 2007;4:251-4.

31. Kuppuswamy R, Govindaraju A, Velusamy G, Balasubramanian R, Balasundarm J, Sellamuthu M. Effect of Dried Fruits of Solanum nigrum LINN against CCl4-Induced Hepatic Damage in Rats. Biol Pharm Bull. 2003;11:1618-9.

32. Muthuligam FAF, Antihepatotoxic Efficacy of Methanolic Extract of Indigofera tinctoria (Linn.) on Paracetamol - Induced Liver Damage in Rats. J Nat Prod Plant Resour. 2012;2:244-50.

33. My, G, Balasubramanian R, Balasundarm J, Sellamuthu M. Effect of Dried Fruits of Solanum nigrum LINN against CCl4-Induced Hepatic Damage in Rats. Biol Pharm Bull. 2003;11:1618-9.

34. Jia JD, Bauer M, Cho JJ, Ruehl M, Milani S, Boigk G, Riecken EO, Schuppan D. Antifibrotic effect of silymarin in rat secondary biliary fibrosis is mediated by downregulation of procollagen alpha1(I) and TIMP-1. J Hepatol. 2001;3:392-8

35. Stahl W, Aust O, Sies H MC. Polidori Analysis of lipophilic antioxidants in human serum and tissues: Tocopherols and carotenoids. J Chromatogr. 2001;936:83-93.

36. Shobana S, Naidu KA. Antioxidant activity of selected Indian spices. Prostaglandins Leukot Essent Fatty Acids. 2000;62:107-10.

37. Renukadevi KP, Sultana SS. Determination of antibacterial, antioxidant and cytotoxicity effect of Indigofera tinctoria on lung cancer cell line NCI- h69. Int J. Pharmacol. 2011;7:356-62.

38. Alves CQ, Brandão HN, David JM, David JP, Lima LS. Avaliação da atividade antioxidante de flavonóides. Diálogos e ciência - Revista da rede ensino FTC. 2007:5:7-8.

39. Devasagayam TPA, Devasagayam KB. Sainis. Immune system and antioxidants, especially those derived from Indian medicinal plants, Indian. J Exp Biol. 2002;6:639-55. 